\section{Лазерная сварка разнородных}

\section{металлов}

С. В. Курынцев ${ }^{1}$, И. Н. Шиганов ${ }^{2}$

1 Казанский национальный исследовательский технический университет им. А. Н. Туполева-КАИ, Казань, Россия

${ }^{2}$ Московский государственный технический университет им. Н. Э. Баумана, Москва, Россия

\begin{abstract}
Представлен количественный и качественный анализ мировых тенденций в области лазерной сварки разнородных металлов за 2016-2019 годы. Определено, что лазерная сварка получила наибольшее распространение для соединений стали с алюминием, титана с алюминием, алюминия с медью. Представлен анализ основных техник и способов сварки разнородных металлов, результаты исследования их влияния на металлургию процесса, микроструктуру и механические свойства соединений. Акцент сделан на описании техники и способов лазерной сварки алюминия со сталью.
\end{abstract}

Ключевые слова: лазерная сварка, разнородные металлы, свариваемость, микроструктура, интерметаллидный слой, механические свойства

Статья получена: 01.08.2020 Принята к публикации: 26.08.2020

\section{ВВЕДЕНИЕ}

Основным трендом современного конструкционного машиностроения является снижение веса конечного изделия за счет использования материалов и конструкций, имеющих высокую прочность и низкий удельный вес [1]. Примером таких материалов являются композиционные материалы на основе углеволокна, высокопрочные дуплексные стали, пористые или полые материалы [2, 3], полученные с применением аддитивных технологий и с учетом топологической оптимизации. Также к таким материалам можно отнести мульти-материалы или гибрид-

\section{Laser Welding of Dissimilar Metals}

\author{
S. V. Kuryntsev' ${ }^{1}$ I. N. Shiganov ${ }^{2}$ \\ ' Kazan National Research Technical University \\ n. a. A. N. Tupolev - KAI, Kazan, Russia \\ ${ }^{2}$ Moscow State Technical University n.a. N. E. Bauman, \\ Moscow, Russia
}

\begin{abstract}
A quantitative and qualitative analysis of world trends in the field of laser welding of dissimilar metals for 2016-2019 is presented. It is highlighted that laser welding is most widespread for joints of steel with aluminum, titanium with aluminum, aluminum with copper. The analysis of the basic techniques and methods of welding dissimilar metals, the results of studying their influence on the metallurgy of the process, the microstructure and mechanical properties of joints. The emphasis is made on the description of the technique and methods of laser welding of aluminum with steel.
\end{abstract}

Key words: laser welding, dissimilar metals, weldability, microstructure, intermetallic layer, mechanical properties

Received on: 01.08.2020 Accepted on: 26.08 .2020

\section{INTRODUCTION}

The main trend of modern structural engineering is to reduce the weight of the final product using materials and structures with high strength and low specific weight [1]. Examples of such materials are composite materials based on carbon fiber, highstrength duplex steels, porous or hollow materials [2, 3], obtained using additive technologies and taking into account topological optimization. In addition, such materials include multi-materials or hybrid structures consisting of several dissimilar materials connected to each other in some way, e.g., by welding, bolting or riveting, gluing, soldering, etc. [4].

As a rule, welded, brazed or glued joints provide the greatest strength and tightness of joints. The adhesion, weldability and solderability of dissimilar materials can be complicated by the difference in 
ные структуры, состоящие из нескольких разнородных материалов, соединенных между собой каким-либо способом, например сваркой, болтовыми или клепаными соединениями, склеиванием, пайкой и т.д. [4].

Как правило, наибольшую прочность и герметичность соединений обеспечивают сварные, паяные или клееные соединения. Склеиваемость, свариваемость и паяемость разнородных материалов, может быть осложнена различием физических и термомеханических свойств соединяемых материалов и их поверхностей $[5,6]$. Что требует необходимости применения сложных гибридных технологий, основанных на термическом, механическом, химическом воздействии на соединяемые заготовки, к таким технологиям относятся сварка-пайка, сварка-склеивание, клинч-соединения [7] и прочие. Например, кузов современного легкового автомобиля по массе состоит, примерно, из 96 кг алюминия, 66 кг стали, 11 кг магния, 7 кг пластика [4], поэтому вопрос соединения разнородных материалов является актуальной и перспективной наукоемкой технологической задачей.

Понимание физических, химических и металлургических процессов, происходящих при сварке и пайке разнородных материалов, является основой для выбора вида и способа сварки, техник и технологии сварки с целью получения соединения с требуемыми характеристиками. При сварке плавлением разнородных металлов необходимо рассматривать как физические свойства соединяемых материалов, так и металлургию их взаимодействия в жидком состоянии, препятствующих образованию качественного сварного соединении [5].

В связи с тем, что сварка плавлением подразумевает непременное расплавление материала в зоне шва и нагрев до температур $\mathrm{T}=0,8 \mathrm{~T}_{\text {пл }}$ в околошовной зоне, необходимо рассматривать процессы взаимодействия соединяемых материалов при плавлении и кристаллизации. Все процессы плавления и кристаллизации, а также образование интерметаллидных соединений отражаются диаграммами состояния двойных систем [8]. По типу диаграммы состояния двух свариваемых материалов можно предусмотреть образование той или иной структуры. При этом следует различать влияние на структуру механизма кристаллизации с одной стороны и последующих фазовых превращений в твердом состоянии с другой. Диаграммы состояния эвтектического и перетектического типов, компоненты которых при плавлении physical and thermomechanical properties of the materials to be joined and their surfaces $[5,6]$. This requires the use of complex hybrid technologies based on thermal, mechanical, and chemical action on the workpieces being joined; such technologies include welding-brazing, welding-gluing, clinchjoints [7] etc. For example, the body of a modern passenger car by weight consists of approximately 96 $\mathrm{kg}$ of aluminum, $66 \mathrm{~kg}$ of steel, $11 \mathrm{~kg}$ of magnesium, $7 \mathrm{~kg}$ of plastic [4], so the issue of joining dissimilar materials is an urgent and promising scienceintensive technological problem.

Understanding the physical, chemical and metallurgical processes occurring during welding and brazing of dissimilar materials is the basis for choosing the type and method of welding, techniques and welding technology in order to obtain a joint with the required characteristics. In fusion welding of dissimilar metals, it is necessary to consider both the physical properties of the materials being joined and the metallurgy of their interaction in the liquid state, which prevents the formation of a high-quality welded joint [5].

Due to the fact that fusion welding implies the inevitable melting of the material in the weld zone and heating to temperatures $\mathrm{T}=0.8 \mathrm{Tm}$ in the heat-affected zone, it is necessary to consider the processes of interaction of the materials to be joined during melting and crystallization. All processes of melting and crystallization, as well as the formation of intermetallic compounds, are reflected in the diagrams of the state of binary systems [8]. By the type of the state diagram of the two materials to be welded, it is possible to envisage the formation of a particular structure. In this case, one should distinguish between the effect on the structure of the crystallization mechanism, on the one hand, and subsequent phase transformations in the solid state, on the other. The phase diagrams of the eutectic and peretectic types, the components of which upon melting form a homogeneous liquid with limited solubility, and in the solid state are practically insoluble in each other, are the most favorable. Melting and crystallization of such materials in the weld produces a homogeneous heterogeneous structure with alternating particles of constituent elements. Fusion welding of such materials is possible without much difficulty. If the components of the materials to be welded during melting and crystallization have limited or unlimited mutual solubility, then during welding of such materials, solid solutions with a concentration smoothly varying from the fusion line will be formed 
образуют однородную жидкость с ограниченной растворимостью, а в твердом состоянии практически не растворимы друг в друге, наиболее благоприятны. При плавлении и кристаллизации таких материалов в шве получается однородная гетерогенная структура с чередующимися частицами составляющих элементов. Сварка плавлением подобных материалов возможна без особых трудностей. Если же компоненты свариваемых материалов при расплавлении и кристаллизации обладают ограниченной или неограниченной взаимной растворимостью, то при сварке таких материалов в шве будут образовываться твердые растворы с плавно изменяющейся от линии сплавления концентрацией. Прочность шва таких соединений может быть достаточно высока. При сварке материалов с ограниченной растворимостью компонентов в шве будет присут ствовать наряду с твердыми растворами эвтектика или перетектика, в зависимости от диаграммы состояния.

Однако существуют материалы, которые не смешиваются в жидком состоянии и образуют диаграммы состояния с полным отсутствием взаимодействия. При расплавлении в шве таких материалов они расслаиваются, не обеспечивая нужных механических свойств. Таким образом, приступая к разработке технологии сварки разнородных материалов необходимо в первую очередь выяснить тип их диаграммы состояния при плав лении и кристаллизации.

На практике основной проблемой, снижающей механические и эксплуатационные свойства сварных соединений из разнородных сплавов, является образование интерметаллидного слоя (ИМС), являющегося очень твердым и хрупким [9]. Интерметаллическая фаза может быть полезной для сплава, являться дисперсным упрочнителем, тормозящим дислокации, в том случае, когда она равномерно распределена между зернами в объеме металла [5]. Однако, если ИМС будет присутствовать в виде непрерывной полосы на границе или на линии сплавления двух металлов, то в этом случае она будет нести угрозу разрушению соединения, слабой областью будет являться линия перехода или ЗТВ от иМС к основному металлу.

В табл. 1 приведены характеристики возможности сварки некоторых пар металлов. Как видно из таблицы отличной свариваемостью обладают только медь и никель. Это связано с тем, что эти материалы обладают химическим сродством, образовывают твердый раствор замещения нео- in the seam. The seam strength of such joints can be quite high. When welding materials with a limited solubility of the components in the weld, along with solid solutions, a eutectic or a permeate will be present, depending on the phase diagram.

However, there are materials that do not mix in a liquid state and form phase diagrams with no interaction at all. When such materials are melted in a seam, they delaminate, not providing the desired mechanical properties. Thus, when starting to develop a technology for welding dissimilar materials, it is necessary, first, to find out the type of their state diagram during melting and crystallization.

In practice, the main problem that reduces the mechanical and operational properties of welded joints from dissimilar alloys is the formation of an intermetallic layer (IML), which is very hard and brittle [9]. The intermetallic phase can be useful for an alloy; it can be a dispersed hardener that inhibits dislocations, if it is evenly distributed between grains in the bulk of the metal [5]. However, if the IML is present in the form of a continuous strip at the interface or on the fusion line of two metals, then in this case it will pose a threat to the destruction of the joint, the weak area will be the transition line or HAZ from the IML to the base metal.

Table 1 shows the characteristics of the possibility of welding some pairs of metals. As you can see from the table, only copper and nickel have excellent weldability. This is because these materials have a chemical affinity and form a solid substitution solution of unlimited solubility. The remaining metal pairs generally have satisfactory weldability. Therefore, an important task is to ensure uniformity of diffusion processes over the thickness of buttwelded materials.

One of the effective methods of welding dissimilar materials is laser welding [10-12]. When welding dissimilar metals, the main advantage is a high welding speed and concentration of energy, which allow minimizing the interaction time of the metals being joined, as a rule, having different melting points, limited mutual solubility, heat capacity and thermal conductivity coefficients. Minimization of the interaction time leads to the minimization of the formation of intermetallic compounds between the metals being welded, which usually have high hardness and brittleness, low thermal and electrical conductivity.

The purpose of the work is a quantitative and qualitative analysis of the world trends in laser welding of dissimilar metals, an overview of world trends, methods and techniques of joining. 
Таблица 1. Свариваемость бинарных комбинаций металлов

Table 1. Weldability of binary metal combinations

\begin{tabular}{|l|c|c|c|c|c|c|}
\hline Металл & $\mathrm{Fe}$ & $\mathrm{Al}$ & $\mathrm{Ti}$ & $\mathrm{Ni}$ & $\mathrm{Mg}$ & $\mathrm{Cu}$ \\
\hline $\mathrm{Fe}$ & +++ & + & + & ++ & - & + \\
\hline $\mathrm{Al}$ & + & +++ & + & + & + & + \\
\hline $\mathrm{Ti}$ & + & + & +++ & + & - & + \\
\hline $\mathrm{Ni}$ & ++ & + & + & +++ & + & +++ \\
\hline $\mathrm{Mg}$ & + & + & + & + & +++ & + \\
\hline $\mathrm{Cu}$ & + & + & + & +++ & + & +++ \\
\hline
\end{tabular}

Примечание: +++ - отличная, ++- хорошая, +- удовлетворительная, - - плохая, нет данных

Note: +++ - excellent, ++- good, +- satisfactory, - - poor, no data available

граниченной растворимости. Остальные пары металлов в основном обладают удовлетворительной свариваемостью. Поэтому важной задачей является обеспечение равномерности диффузионных процессов по толщине свариваемых встык материалов.

Одним из эффективных методов сварки разнородных материалов является лазерная сварка [10-12]. При сварке разнородных металлов основным преимуществом является высокая скорость сварки и концентрированность энергии, позволяющие, минимизировать время взаимодействия соединяемых металлов, как правило, имеющих разную температуру плавления, ограниченную взаимную растворимость, коэффициенты теплоемкости и теплопроводности. Минимизация времени взаимодействия приводит к минимизации образования интерметаллидов между свариваемыми металлами, которые обычно имеют высокую твердость и хрупкость, низкую тепло- и электропроводность.

Цель работы - количественный и качественный анализ мировых тенденций лазерной сварки разнородных металлов, обзор мировых трендов, способов и техник соединения.

\section{АНАЛИЗ ТЕНДЕНЦИЙ МИРОВЫХ ПУБЛИКАЦИЙ ПО ЛАЗЕРНОЙ СВАРКЕ РАЗНОРОДНЫХ МАТЕРИАЛОВ}

Как показывает анализ публикаций по реферативной базе данных Scopus за последние 4 года по теме лазерная сварка разнородных металлов опубликовано около 270 статей, 70\% из которых в высоко-

\section{ANALYSIS OF TRENDS IN WORLD PUBLICATIONS ON LASER WELDING OF DISSIMILAR MATERIALS}

As the analysis of publications on the Scopus abstract database shows, over the past 4 years on the topic of laser welding of dissimilar metals, about 270 articles have been published, $70 \%$ of which are in high-rated journals, the rest in conference proceedings and translated journals. In fig. 1 shows the distribution of the number of articles on laser welding of various pairs of metals for 2016-2019 inclusive. As you can see, the largest number of publications is devoted to joining steel to aluminum (26\%), these joints are widely used in the automotive industry, therefore, these works mainly describe the technologies of welding or welding-brazing of sheet blanks of small thicknesses (up to 2-3 mm). In second place among metal pairs is titanium + aluminum pair (9\%); these joints are widely used in aircraft and rocketry, space products, in which the main requirement is weight minimization. It should also be noted here that titanium-magnesium joints (5\%) are also used in the above-mentioned industries. In third place are joints of aluminum and copper $(8 \%)$, this pair of metals is used in the electrical and thermal power
$26 \% \mathrm{Fe}+\mathrm{Al}$
$9 \% \mathrm{Ti}+\mathrm{Al}$
$6 \% \quad \mathrm{Fe}+\mathrm{Ti}$
$6 \% \mathrm{Fe}+\mathrm{Ni}$
$3 \% \quad \mathrm{Ni}+\mathrm{Ti}$
$5 \% \quad \mathrm{Ti}+\mathrm{Mg}$
$8 \% \mathrm{Cu}+\mathrm{Al}$
$3 \% \mathrm{Cu}+\mathrm{Fe}$
$9 \% \quad$ Me + не Me
9\% $\mathrm{Fe}+$ разные сплавы
16\% Остальные

Puc. 1. Диаграмма распределения тем статей по лазерной сварке разнородных метаплов (2016-2019)

Fig. 1. Diagram of distribution of topics of articles on laser welding of dissimilar metals (2016-2019) 
рейтинговых журналах, остальные в материалах конференций и переводных журналах. На рис. 1 представлено распределение количества статей по лазерной сварке различных пар металлов за 20162019 года включительно. Как видно, наибольшее количество публикаций посвящено соединению стали с алюминием (26\%), данные соединения широко применяются в автостроении, поэтому в данных работах, в основном, описываются тех нологии сварки или сварки-пайки листовых заготовок малых толщин (до 2-3 мм). На втором месте среди пар металлов находится пара титан + алюминий (9\%), данные соединения широко применяются в авиа- и ракетостроении, изделиях космического назначения, в которых основным требованием является минимизация веса. Здесь же следует отметить и соединения титана с магнием (5\%), которые также применяются в выше указанных отраслях. На третьем месте нахо дятся соединения алюминия и меди (8\%), данная пара металлов применяется в электротехниче ской и теплоэнергетической промышленностях. Публикации об остальных парах металлов, таких как, никель + титан, титан + сталь, медь + сталь, никель + сталь, титан + магний составляют от 3 до 6\% от общего количества статей.

Следует отметить, что количество статей по теме соединение металлических материалов с неметаллическими (углеволоконными композитами, органическими стеклами, пластмассами) с применением лазерного излучения около 9\% от общего объема. Как правило, это нахлесточный тип соединения, при котором лазерным лучом воздействуют на металл или на неметаллический материал. При воздействии лазерным лучом на металл осуществляется его нагрев или плавление на неполную глубину в зависимости от толщины, неметаллический материал, находящийся с противоположной стороны нагревается и в вязко текучем состоянии взаимодействует с нагретым металлом. Таким образом, образуется не прочное, но герметичное соединение [13].

\section{ТЕХНОЛОГИЧЕСКИЕ ОСОБЕННОСТИ ЛАЗЕРНОЙ СВАРКИ РАЗНОРОДНЫХ МЕТАЛЛОВ}

Основными технологическими приемами, применяемыми при лазерной сварке разнородных металлов, являются:

- смещение лазерного луча на один из свариваемых металлов;

- применение промежуточных металлов или нанесение покрытий. industries. Publications about other metal pairs, such as nickel + titanium, titanium + steel, copper + steel, nickel + steel, titanium + magnesium, account for 3 to $6 \%$ of the total number of articles.

It should be noted that the number of articles on the topic of joining metallic materials with nonmetallic (carbon fiber composites, organic glass, plastics) using laser radiation is about $9 \%$ of the total. As a rule, a laser beam is applied to a metal or non-metallic material in this lap joint type. When a metal is exposed to a laser beam, it is heated or melted to an incomplete depth, depending on the thickness, the non-metallic material on the opposite side is heated and interacts with the heated metal in a viscous fluid state. Thus, a not strong but tight connection is formed [13].

\section{TECHNOLOGICAL FEATURES OF LASER WELDING OF DISSIMILAR METALS}

The main technological methods used in laser welding of dissimilar metals are:

- offset of the laser beam to one of the welded metals;

- use of intermediate metals or coating.

When choosing the offset of the laser beam to one of the metals being welded, they are guided by various factors and properties of the metals being joined: the degree of absorption of laser radiation by the metal of a certain wavelength, the melting point, the wettability of one component to another, or vice versa, the mutual solubility of the components at the level of the crystal structure, the difference in heat capacity and thermal conductivity.

For example, when welding well-weldable copper to stainless steel, the laser beam is displaced onto the steel, the steel melts, wets and heats the copper through thermal conduction (heat transfer
$11 \% \quad 2016$
$11 \% \quad 2017$
$46 \% \quad 2018$
$32 \% \quad 2019$

Puc. 2. Диаграмма распределения количества статей по иазерной сварке разнородных метаплов (2016-2019)

Fig. 2. Diagram of the distribution of the number of articles on laser welding of dissimilar metals (2016-2019) 
При выборе смещения лазерного луча на один из свариваемых металлов руководствуются различными факторами и свойствами соединяемых металлов - степенью поглощения металлом лазерного излучения определенной длины волны, температурой плавления, смачиваемостью одного компонента другим или наоборот, взаимной растворимостью компонентов на уровне кристаллического строения, отличием теплоемкости и теплопроводности.

Например, при сварке хорошо свариваемых меди с нержавеющей сталью, лазерный луч смещается на сталь, сталь расплавляется, смачивает и нагревает медь посредством тепловой кондукции (теплопередачи в твердом теле), образуя металлические связи. Если луч направить на медь, то, во-первых, лазерное излучение почти всех длин волн в ИК-спектре будет отражаться на 99\% [11], во-вторых, теплопроводность меди в 5 раз больше чем железа $[8,14]$, тепло, образованное воздействием лазерного излучения будет рассеиваться, а не плавить медь и т. д.

В случае сварки ограничено свариваемых металлов, например, стали с алюминием в основном лазерный луч смещается на алюминий, хотя его теплопроводность и степень отражения лазерного излучения выше, чем у стали, но смачиваемость стали расплавленным жидким алюминием выше, чем смачиваемость алюминия жидким железом [6]. Также температура плавления железа почти в 3 раза выше чем температура плавления алюминия, то есть плавление железа может привести к кипению алюминия, и как следствие, к образованию дефектов. При этом посредством смещения лазерного луча в диапазоне 0,1-2 мм в зависимости от скорости и толщины свариваемых заготовок можно управлять толщиной образования ИМС.

Применение промежуточных металлов или нанесение покрытий, металлургически совместимых с обоими плохо свариваемыми между собой металлами, широко распространенная техника, применяемая в различных видах сварки, таких как, диффузионная, взрывом, давлением и т.д. [5, 9]. Если в указанных видах сварки данная техника сварки применяется для нахлесточного типа соединений, то в случае лазерной сварки она применяется и для нахлесточных соединений, и для стыковых. При сварке стыковых соединений промежуточный металл может плавиться как напрямую лазерным лучом, так и посредством тепловой кондукции при смещении лазерного луча на один из свариваемых in a solid), forming metallic bonds. If the beam is directed to copper, then, firstly, laser radiation of almost all wavelengths in the IR spectrum will be reflected by 99\% [11], and secondly, the thermal conductivity of copper is 5 times greater than that of iron $[8,14]$, heat generated by exposure to laser radiation will scatter rather than melt copper, etc.

In the case of welding limited weldable metals, e.g., steel with aluminum, basically the laser beam is shifted to aluminum, although its thermal conductivity and the degree of reflection of laser radiation are higher than that of steel, but the wettability of steel by molten liquid aluminum is higher than the wettability of aluminum by liquid iron [6]. Also, the melting point of iron is almost 3 times higher than the melting point of aluminum, that is, the melting of iron can lead to boiling of aluminum, and as a result, to the formation of defects. In this case, by shifting the laser beam in the range of $0.1-2 \mathrm{~mm}$, depending on the speed and thickness of the workpieces being welded, the thickness of the IML formation can be controlled.

The use of intermediate metals or the application of coatings that are metallurgically compatible with both poorly welded metals are a widespread technique used in various types of welding, such as diffusion, explosion, pressure, etc. [5, 9]. If in the indicated types of welding this welding technique is used for the overlap type of joints, then in the case of laser welding it is used for both overlap joints and butt joints. When welding butt joints, the intermediate metal can be melted either directly by the laser beam or by thermal conduction when the laser beam is displaced onto one of the components to be welded. In the case of lap joints, the intermediate metal is heated conductively and does not always melt, since it is not directly affected by the laser beam. As a rule, most of the joints obtained by the above methods are weldedbrazed. That is, for one metal, the process is characterized as welding: it melts, wetting another metal, for which the process is characterized as brazing. The mechanical properties of such compounds can reach $70-90 \%$ of the properties of a less strong metal [4].

In these technological methods, through a high degree of controllability of the parameters of laser radiation, it is possible to control overheating and the thickness of the transition layer or IML, which can significantly improve the quality of the connection and its mechanical and operational properties. 
компонентов. В случае нахлесточных соединений промежуточный металл нагревается кондуктивно и не всегда плавится, так как напрямую лазерный луч на него не воздействует. Как правило, боль шая часть соединений, полученных вышеуказанными способами, являются сварно-паяными. То есть для одного металла процесс характеризуется как сварка: он расплавляется, смачивая другой металл, для которого процесс характеризуется как пайка. Механические свойства таких соединений могут достигать 70-90\% от свойств менее прочного металла [4].

В указанных технологических приемах, посредством высокой степени контролируемости параметров лазерного излучения можно контро лировать, перегрев и толщину переходного слоя или ИМС, что позволяет существенно улучшить качество соединения и его механические и эксплуатационные свойства.

\section{ЛАЗЕРНАЯ СВАРКА АЛЮМИНИЕВЫХ СПЛАВОВ СО СТАЛЬЮ}

Как было сказано выше, наиболее распространенной парой свариваемых лазерной сваркой металлов являются сталь с алюминием, так как получили наибольшее распространение в качестве конструкционных материалов. Основные физические свойства алюминия и железа представлены в табл. 2. Из представленных данных видно, что свойства отличаются значительно, в том числе и на уровне атомного строения, в частности постоянная решетки отличается почти в 1,5 раза, атомный радиус алюминия равен 143 пм, железа 126 пм, кристаллическая решетка алюминия одинакова только с гамма-железом.

Железо является переходным металлом. В соответствии с диаграммой состояния образует с алюминием эвтектику и имеет низкую растворимость в твердом алюминии. Алюминий в свою очередь

\section{LASER WELDING}

\section{OF ALUMINUM ALLOYS WITH STEEL}

As mentioned above, the most common pair of laser-welded metals are steel with aluminum, since they are most widely used as structural materials. The main physical properties of aluminum and iron are presented in Table 2. It can be seen from the presented data that the properties differ significantly, including at the level of atomic structure, in particular, the lattice constant differs by almost 1.5 times, the atomic radius of aluminum is $143 \mathrm{pm}$, iron $126 \mathrm{pm}$, the crystal lattice of aluminum is the same only with gamma iron.

Iron is a transition metal. In accordance with the phase diagram, it forms a eutectic with aluminum and has a low solubility in solid aluminum. Aluminum, in turn, dissolves well in alpha iron, forming the following stable phases $\mathrm{Fe}_{3} \mathrm{Al}$, $\mathrm{FeAl}_{2}$, $\mathrm{Fe}_{2} \mathrm{Al}_{5}, \mathrm{FeAl}_{3}$, each of which has a certain region of homogeneity $[5,8,15]$. In view of the indicated differences in the structure and properties of aluminum and iron, fusion welding of these metals is a science-intensive technological task.

The work [16] presents the main types of weldedbrazed joints used in the automotive industry (Fig. $3 \mathrm{a}, \mathrm{b}$ ), in the technology used, the laser beam was directed to the filler wire, which in the molten state interacts with DX51D steel and AlMgSil alloy (Fig. 4), the materials being joined are not melted by the laser beam.

The authors presented the results of a study of laser welding-brazing using various filler materials (AlSi5, Alsi12, ZnAl2), the maximum strength values were obtained for specimens with a zincbased filler material (220 MPa), specimens with an aluminum-based filler material (160-180 MPa). Fracture of the samples was observed along the HAZ of aluminum (Fig. $5 \mathrm{a}, \mathrm{b}$ ).

Таблица 2. Физические свойства железа и алюминия Table 2. Physical properties of iron and aluminum

\begin{tabular}{|c|c|c|c|c|c|c|}
\hline $\begin{array}{l}\text { Металл } \\
\text { Metal }\end{array}$ & $\begin{array}{l}\text { Температура } \\
\text { плавления, } \\
{ }^{\circ} \mathrm{C} \\
\text { Melting } \\
\text { point, } \\
{ }^{\circ} \mathrm{C}\end{array}$ & $\begin{array}{c}\text { KTP } \\
0-100^{\circ} \mathrm{C} \\
{ }^{\circ} \mathrm{C}^{-1} \cdot 10^{6} \\
\mathrm{CTE} \\
0-100^{\circ} \mathrm{C} \\
{ }^{\circ} \mathrm{C}^{-1} \cdot 10^{6}\end{array}$ & $\begin{array}{c}\text { Коэффициент тепло- } \\
\text { проводности, при } \\
20^{\circ} \mathrm{C}, \mathrm{BT} /(\mathrm{M} \cdot \mathrm{K}) \\
\text { Thermal conductivity } \\
\text { coefficient, at } 20^{\circ} \mathrm{C} \text {, } \\
\mathrm{W} /(\mathrm{m} \cdot \mathrm{K})\end{array}$ & $\begin{array}{c}\text { Тип кристаллической } \\
\text { решетки/постоянная } \\
\text { решетки, нм } \\
\text { Type of crystal } \\
\text { lattice/lattice } \\
\text { constant, nm }\end{array}$ & $\begin{array}{l}\text { Атомный } \\
\text { радиус, } \\
\text { пм } \\
\text { Atomic } \\
\text { radius, } \\
\text { pm }\end{array}$ & $\begin{array}{c}\text { Электроотрица- } \\
\text { тельность (шкала } \\
\text { Полинга) } \\
\text { Electronegativity } \\
\text { (Pauling scale) }\end{array}$ \\
\hline $\mathrm{Al}$ & 660 & 24 & 204 & $\begin{array}{l}\text { ГЦК/ 0,4 } \\
\text { FCС / 0,4 }\end{array}$ & 143 & 1,61 \\
\hline $\mathrm{Fe}$ & 1539 & 12 & 78 & $\begin{array}{l}\text { ГЦК, ОЦК/0,28 } \\
\text { FCC, VСС / 0,28 }\end{array}$ & 126 & 1,83 \\
\hline
\end{tabular}




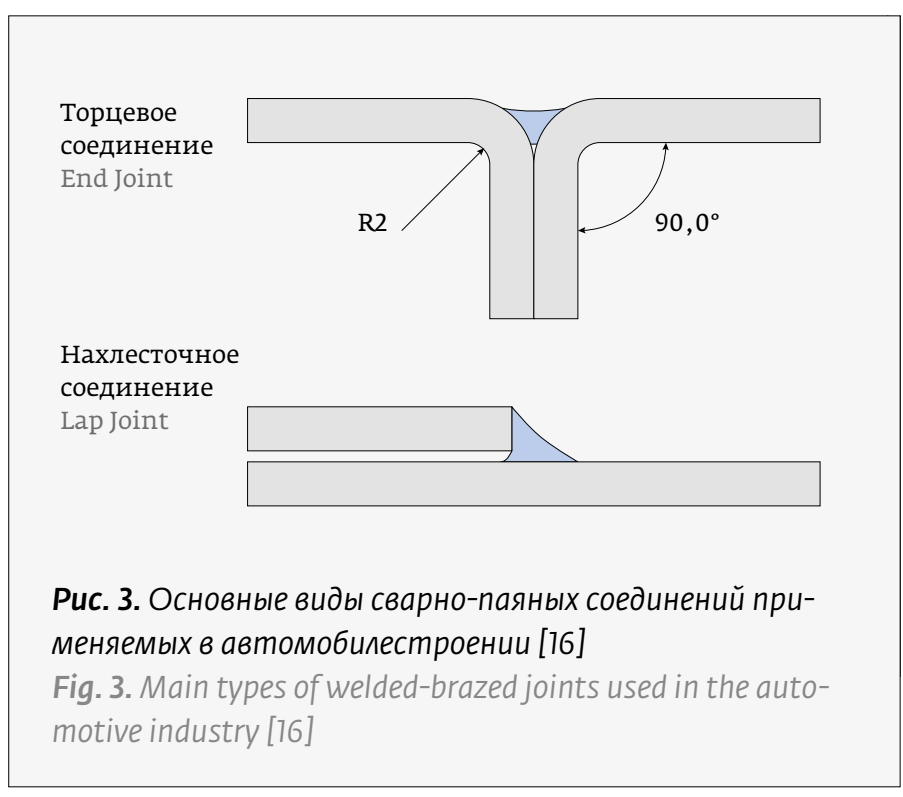

хорошо растворяется в альфа-железе, образуя следующие стабильные фазы $\mathrm{Fe}_{3} \mathrm{Al}, \mathrm{FeAl}_{2}, \mathrm{Fe}_{2} \mathrm{Al}_{5}, \mathrm{FeAl}_{3}$, каждая из которых обладает определенной областью гомогенности $[5,8,15]$. В виду указанных отличий строения и свойств алюминия и железа, сварка плавлением данных металлов является наукоемкой технологической задачей.

В работе [16] представлены основные виды сварно-паяных соединений применяемых в автомобилестроении (рис. 3 a, b), в использованной технологии лазерный луч направлялся на присадочную проволоку, которая в расплавленном состоянии взаимодействует со сталью DX51D и сплавом AlMgSil (рис. 4), соединяемые материалы при этом лазерным лучом не расплавляются.

Авторами представлены результаты исследования лазерной сварки-пайки с применением различных присадочных материалов (AlSi5, AlSi12, ZnAl2), максимальные значения прочности были получены у образцов с присадочным материалом на основе цинка (220 МПа), образцы с присадочным материалом на основе алюминия (160-180 МПа). Разрушение образцов наблюдалось по ЗТВ алюминия (рис. $5 \mathrm{a}, \mathrm{b}$ ).

Влияние формы разделки кромок (рис. 6a, b, с) при сварке встык алюминиевого сплава 6061-Т6 и стали DP590 пред-
The influence of the shape of the groove (Fig. 6 a, b, c) in butt welding of aluminum alloy 6061-T6 and steel DP590 is presented by the authors [17], and a comparative analysis of the results obtained with mathematical modeling of the distribution of the thermal field depending on the shape of the groove is carried out. The proposed models are verifiable. The tensile strength of the samples under study is in the range 108-145 $\mathrm{MPa}$, the elongation is less than $1 \mathrm{~mm}$, the highest values were for samples with the groove shown in Fig. 6c, they also had the minimum IML thickness $(8.8 \mu \mathrm{m})$. The smallest value of ultimate tensile strength was observed for specimens with the groove shape shown in Fig. 6 a, they also had the greatest thickness of the IML.

In works [18-20], studies of overlapping welding of aluminum and steel sheets are described. In particular, in [18], studies are carried out on the influence of heat input and welding technology (exposure to a beam from the side of aluminum or from the side of steel) on the mechanical properties of welded joints. The authors conclude that the welding technique, in which the laser beam melts aluminum, is not preferable, since molten aluminum interacts too actively with steel, this leads to the formation of IML of large thickness, and in some cases to the formation of cracks.

Modeling the propagation of temperature fields during laser welding with a defocused beam with a diameter of $13 \mathrm{~mm}$ overlapping steel and aluminum, when exposed to a beam on steel, is described by the authors [19]. The proposed model and the established boundary conditions show the adequacy

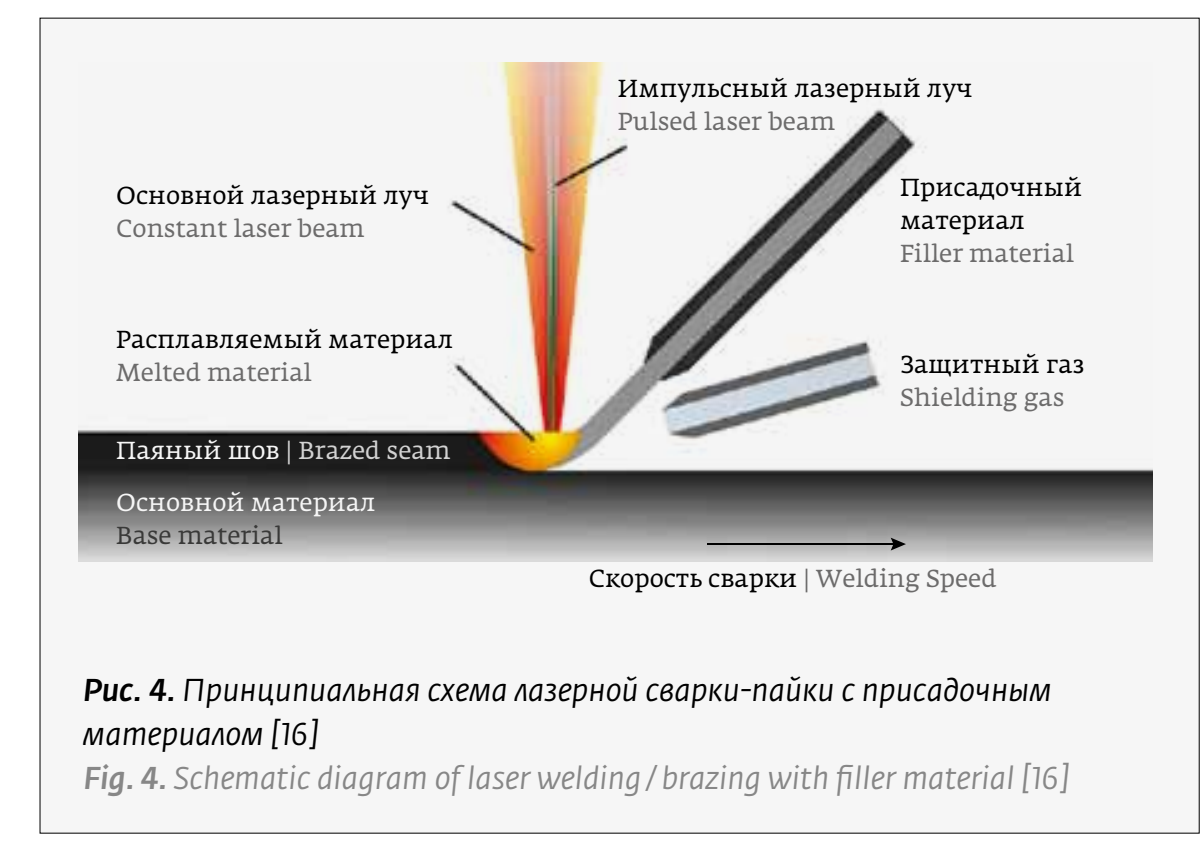


ставлено авторами [17], также проведен сравнительный анализ полученных результатов с мате матическим моделированием распределения теплового поля в зависимости от формы разделки кромок, предложенные модели являются верифицируемыми. Предел прочности при растяжении исследуемых образцов находится в пределах 108-145 МПа, удлинение менее 1 мм, наиболь шие значения имели образцы с формой разделки, представленной на рис. 6с, они же имели мини мальную толщину ИМС (8,8 мкм). Наименьшие значение предела прочности при растяжении имели образцы с формой разделки кромок, представленной на рис. 6а, они же имели наибольшую толщину ИМС.

В работах [18-20] описываются исследования сварки листов из алюминия и стали внахлест. В частности, в работе [18] проводятся исследования влияния погонной энергии и техники сварки (воздействие лучом со стороны алюминия или со стороны стали) на механические свойства сварных соединений. Авторы заключают, что техника сварки, при которой лазерный луч плавит алюминий, не является предпочтительной, так как расплавленный алюминий слишком активно взаимодействует со сталью, это приводит к образованию ИМС большой толщины, а в некоторых случаях к образованию трещин.

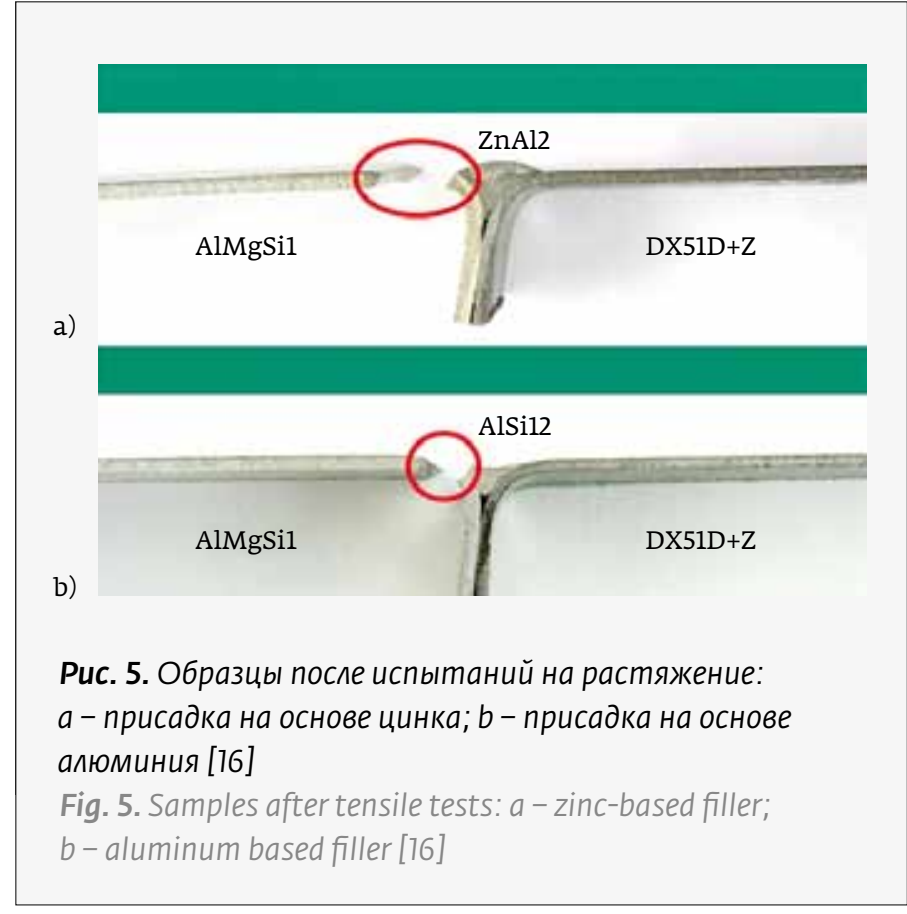

of the thermal cycle model and a real experiment, in particular, the depth and width of the penetration, on which the mechanical properties depend. The authors establish that the joint has the maximum mechanical properties during shear tests under the condition of the minimum IML and the maximum

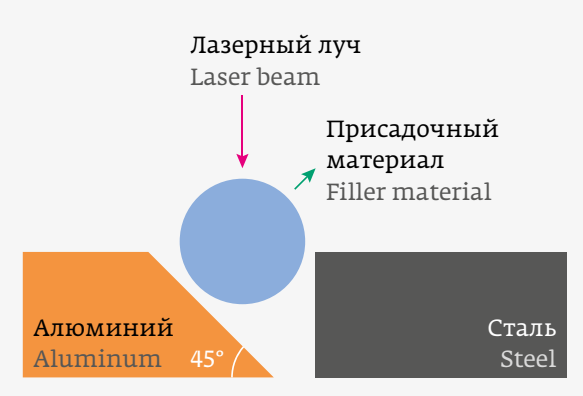

a)

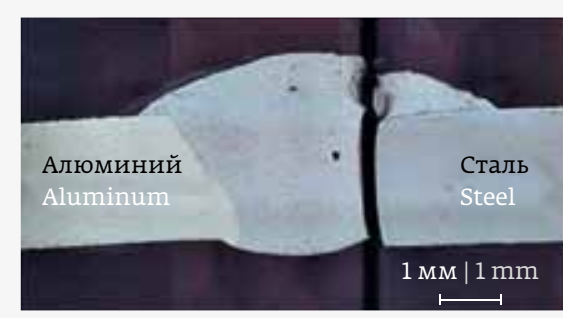

d)

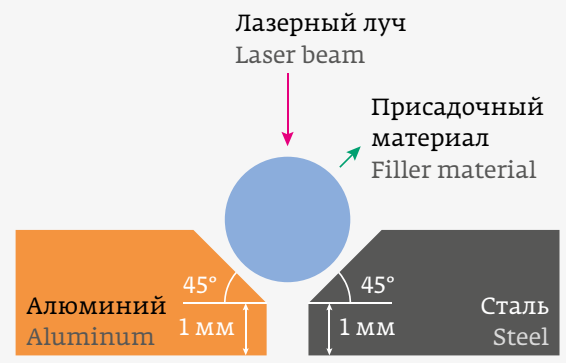

b)

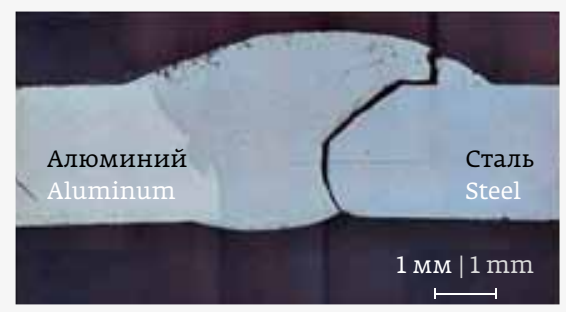

e)

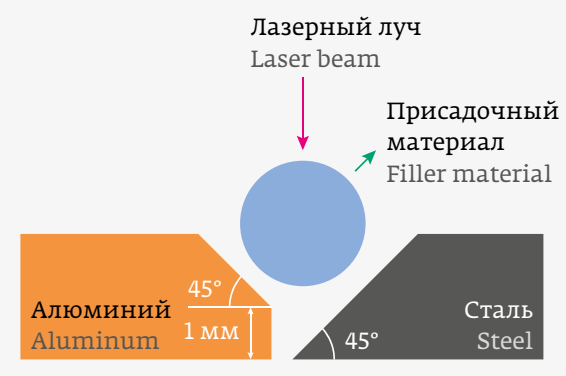

c)

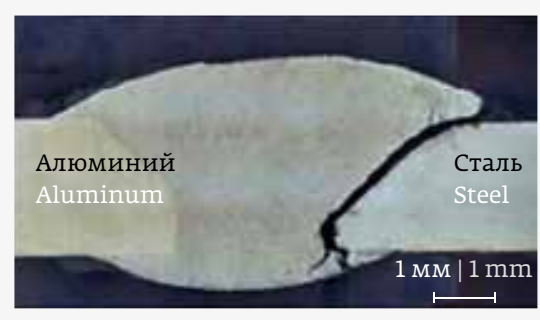

f)

Fig. 6. Variants of edge preparation $(a, b, c)$, microstructure after tensile tests $(d, e, f)[17]$

Puc. 6. Варианты разделки кромок ( $a, b, c)$, микроструктура после испытаний на растяжение $(d, e, f)[17]$ 
Моделирование распространения температурных полей при лазерной сварке расфокусированным лучом диаметром 13 мм внахлест стали и алюминия, при воздействии лучом на сталь описывается авторами [19]. Предложенная модель и установленные граничные условия показывают адекватность модели термического цикла и реального эксперимента, в частности глубину и ширину проплава, от которых зависят механические свойства. Авторы устанавливают, что максимальные механические свойства при испытаниях на срез соединение имеет при условии минимального ИМС и максимальной ширины области взаимодействия стали и алюминия, обеспечиваемой расфокусированным лазерным лучом.

В работе [20] описываются исследования сварки стали и алюминия раздвоенным лазерным лучом внахлест, при воздействии со стороны стали, при этом луч раздваивали вдоль или поперек направления сварки, варьируется расстояние между лучами и соотношение мощности лучей. Максимальные механические свойства при испытаниях на срез (109,2 Н/мм) были получены при соотношении мощности лучей $3 / 2$ и их поперечном расположении относительно направления сварки.

Результаты исследований и механических испытаний корпусного элемента автобуса, полученного лазерной сваркой стали с алюминием приводятся в работе [21]. В данной работе показано, что полученные соединения имеют необходимые прочностные характеристики (125-130 МПа), достаточные для обеспечения безопасной эксплуатации пассажирских транспортных средств.

Гибридная лазерно-дуговая сварка стали и алюминия встык описывается в работах [22, 23], в частности исследуется влияние смещения лазерного луча, расстояние между лучом и дугой, и влияние параметров режимов сварки. Авторами [22] было проведено сравнение двух техник - смещение лазерного луча на сталь и гибридная лазернодуговая сварка (дуга и луч направлены в стык). В результате исследований было установлено, что более предпочтительной техникой является смещение луча на сталь, так как в данном случае процесс сопровождается более высокими скоростями охлаждения по сравнению с лазерно-дуговой сваркой и способствует минимизации толщины образовывавшегося ИМС (6 мкм).

Технология лазерно-дуговой сварки-пайки с промежуточным материалом, спрессо- width of the interaction region between steel and aluminum, provided by a defocused laser beam.

In [20], studies of welding of steel and aluminum with a bifurcated laser beam with an overlap, when exposed to the steel, are described, while the beam was bifurcated along or across the welding direction, the distance between the beams and the ratio of the power of the beams vary. The maximum mechanical properties in shear tests $(109.2 \mathrm{~N} / \mathrm{mm})$ were obtained with a ratio of the power of the beams $3 / 2$ and their transverse arrangement relative to the welding direction.

The results of research and mechanical tests of a bus body element, obtained by laser welding of steel with aluminum, are given in [21]. In this work, it is shown that the obtained joints have the necessary strength characteristics (125-130 MPa), sufficient to ensure the safe operation of passenger vehicles.

Hybrid laser-arc butt welding of steel and aluminum is described in [22, 23], in particular, the effect of laser beam offset, the distance between the beam and the arc, and the effect of welding parameters are investigated. The authors of [22] compared two techniques - the shift of the laser beam onto steel and hybrid laser-arc welding (the arc and the beam are directed into the joint). As a result of the research, it was found that the more preferable technique is to shift the beam to steel, since in this case the process is accompanied by higher cooling rates compared to laser-arc welding and helps to minimize the thickness of the formed IML $(6 \mu \mathrm{m})$.

The authors of [23] describe the technology of laser-arc welding-brazing with an intermediate material pressed from a powder based on aluminum (Al80Zn8Mg7Mn2Si2), while the beam and arc are directed to the intermediate material, a comparison is made with laser welding without the use of an electric arc. The authors conclude that the use of two heat sources is an effective technology for increasing the spreading of the intermediate material and the formation of a welded-brazed joint with a tensile strength of $163 \mathrm{MPa}$ and an IML thickness of 8.7 $\mu \mathrm{m}$.

The paper [24] investigates the technology of laser welding, and the features of subsequent machining of rods made of steel and aluminum. An interesting and promising technology for producing $\mathrm{T}$-joints was proposed by the authors [25]. The essence of the technology lies in the fact that a sheet of aluminum is inserted into a groove previously prepared on a steel sheet with a permissible variation of $0.2 \mathrm{~mm}$ on each side, then on the reverse side of the steel sheet, a defocused laser beam is heated along the trajectory 
ванным из порошка на основе алюминия (Al80Zn8Mg7Mn2Si2), описана авторами [23], при этом луч и дуга направлены на промежуточный материал, проводится сравнение с лазерной свар кой без применения электрической дуги. Авторы заключают, что использование двух источников тепла является эффективной технологией для увеличения растекания промежуточного мате риала и образования сварно-паяного соединения, имеющего предел порочности 163 МПа и толщину ИМС 8,7 мкм.

В работе [24] исследуется технология лазерной сварки, и особенности последующей механиче ской обработки стержней из стали и алюминия. Интересная и перспективная технология полу чения тавровых соединений предложена авторами [25]. Сущность технологии заключается в том, что в предварительно подготовленный на стальном листе паз с допуском 0,2 мм с каждой стороны, вставляется лист из алюминия, затем с обратной стороны стального листа, расфокусированным лазерным лучом производится нагрев по траектории паза (рис. 7а). Мощность лазер ного луча подбирается таким образом, чтобы происходил нагрев стального листа, через который посредством тепловой кондукции происходил бы нагрев и плавление алюминия, аналогично технологии представленной в работе [19]. Это в свою очередь посредством смачивания стали расплавленным алюминием привело бы к образованию металлических связей между торцом алюминиевого листа и металлом поло сти паза стального листа. Также, в результате неравномерного термического воздействия на стальной лист в области меньшей толщины, происходит механическое сжатие алюминиевого листа металлом полости паза (рис. 7a, b), что повышает механические характеристики соеди нения. Толщина ИМС в соединении, получен ном посредством предложенной техники около 5 MKM.

Эффект влияния смещения лазерного луча, совершающего круговые колебательные движения по диаметру 0,5 мм, на алюминий при гибрид ной лазерно-дуговой сварке встык со сталью листов толщиной 1,8 мм, описан авторами [26]. Основным технологическим параметром выбрано расстояние смещения начальной точки воздействия лазерного луча, находящееся в пределах 0-1 мм (шаг 0,2 мм) от линии стыка алюминия и стали (рис. 8).

Образовавшееся соединение является сварно паяным, так как расплавлению был подвергнут

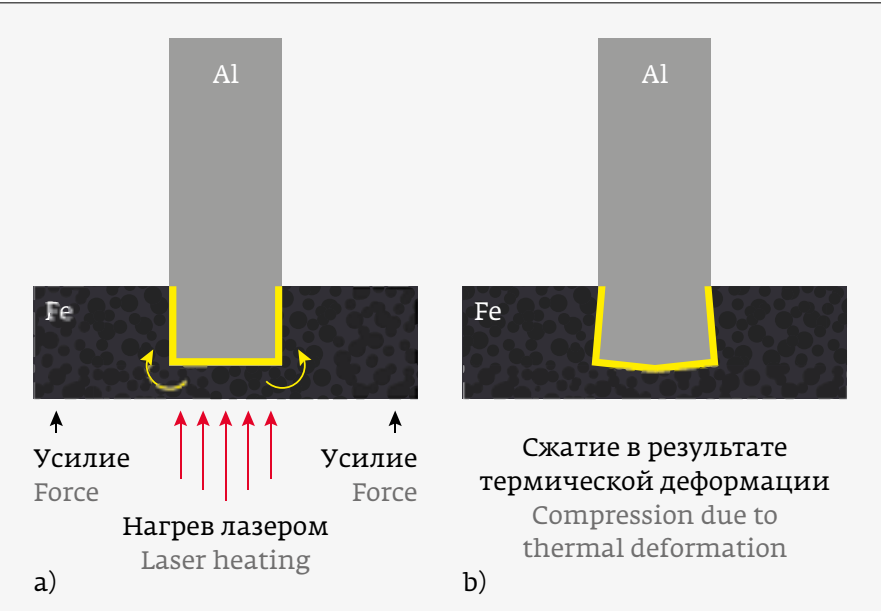

Puc. 7. Схема таврового соединения из стали и алюминия [25]

Fig. 7. Diagram of a T-joint made of steel and aluminum [25]

of the groove (Fig. $7 \mathrm{a}$ ). The power of the laser beam is selected in such a way that the steel sheet is heated, through which, through thermal conduction, heating and melting of aluminum would occur, similar to the technology presented in [19], which in turn, by wetting the steel with molten aluminum, would lead to the formation of metal bonds between the end face of the aluminum sheet and the metal of the groove cavity of the steel sheet. Also, as a result of uneven thermal effect on the steel sheet in the area of smaller thickness, mechanical compression of the aluminum sheet by the metal of the groove cavity occurs (Fig. 7 a, b), which increases the mechanical characteristics of the joint. The thickness of the IML in the joint obtained using the proposed technique is about 5 microns.

The effect of the displacement of a laser beam performing circular oscillatory movements along a diameter of $0.5 \mathrm{~mm}$ on aluminum in hybrid laserarc butt welding with steel sheets $1.8 \mathrm{~mm}$ thick is described by the authors [26]. The main technological parameter is the distance of displacement of the initial point of the laser beam impact, which is within the range of $0-1 \mathrm{~mm}$ (step of $0.2 \mathrm{~mm}$ ) from the line of joint between aluminum and steel (Fig. 8).

The resulting joint is welded-brazed, since aluminum was melted, however, in contrast to welding without circular oscillations with a laser beam, the researchers discovered some features of the welded-brazed joint obtained by the presented technology. When melting aluminum-based alloys with a laser beam, a cone-shaped weld pool is formed 


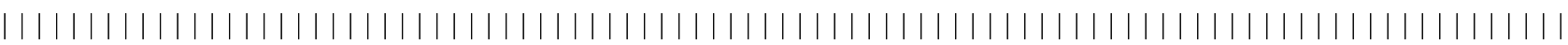

алюминий, однако, в отличие от сварки без круговых колебаний лазерным лучом исследователи обнаружили некоторые особенности сварно-паяного соединения, полученного представленной технологией. При плавлении сплавов на основе алюминия лазерным лучом без колебаний образуется конуснообразная сварочная ванна, тогда как при плавлении лазерным лучом, совершающим круговые колебания, будет образовываться цилиндрообразная сварочная ванна. Это, в свою очередь, приводит к более равномерному по глубине взаимодействию расплавленного алюминия со сталью в нижней и верхней частях соединения и как результат - к образованию более однородного по толщине ИМС ( 1,3 мкм). Посредством смещения лазерного луча на 0,8 мм были получены соединения, имеющие предел прочности около 160 МПа. Также авторами пред-

without oscillation, while when melting with a circularly oscillating laser beam, a cylindrical weld pool will be formed. This, in turn, leads to a more uniform in depth interaction of molten aluminum

Puc. 8. Схема смещения и траектории лазерного пуча [26]

Fig. 8. Diagram of displacement and trajectory of the laser beam [26]

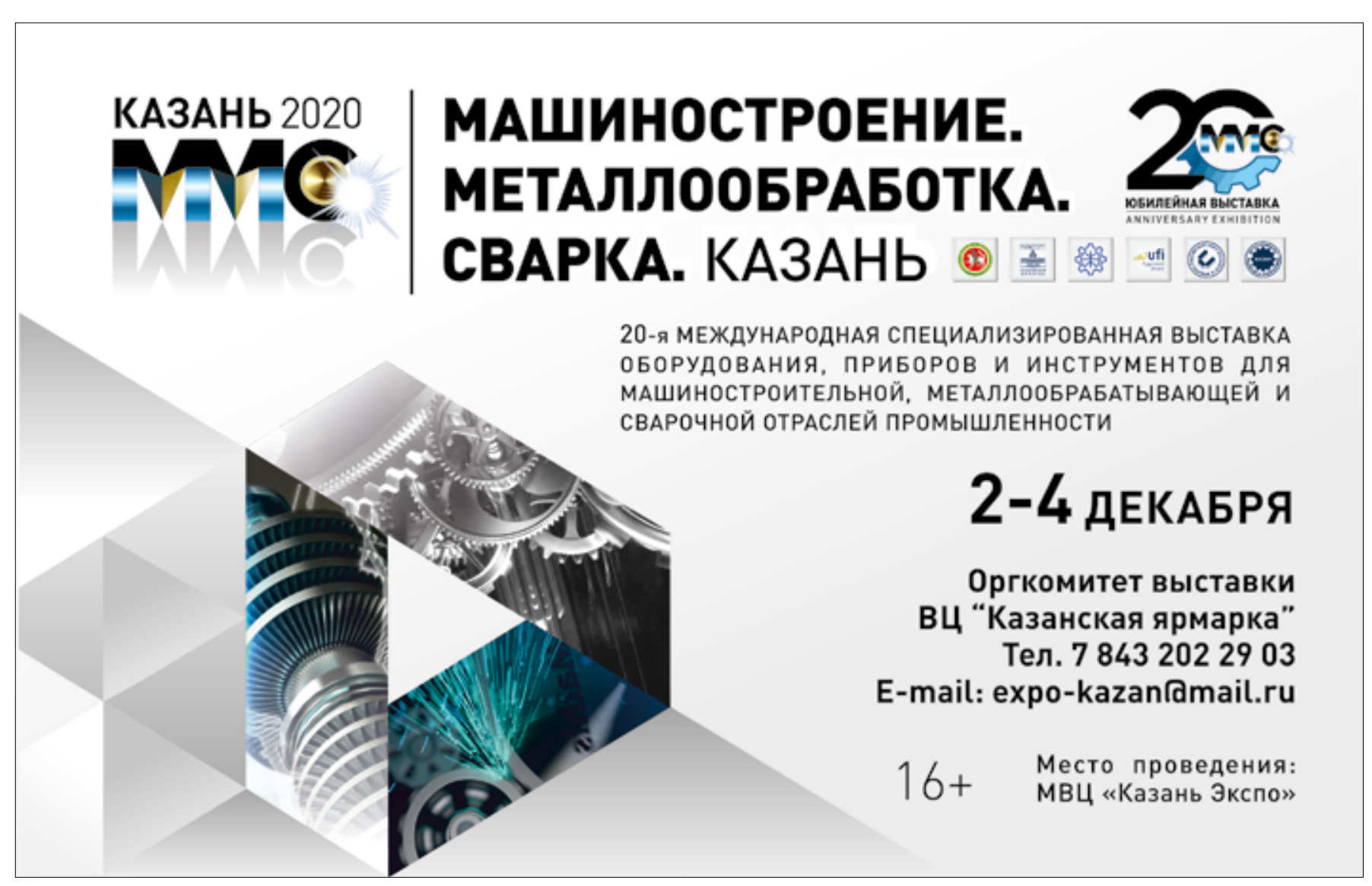


ставлена модель взаимодействия атомов алюминия и железа и модель образования ИМС в зависимости от расстояния смещения.

В остальных работах описывается влияние способов, основных технологических параметров, техник и приемов, таких как выбор присадочного материала, защитного газа, применение различных покрытий соединяемых металлов, использование двухлучевой лазерной сварки, опубликовано несколько работ по дистанционной высокоскоростной сварке.

\section{ЗАКЛЮЧЕНИЕ}

Результаты исследования позволяют сделать следующие выводы:

1. Лазерная сварка является перспективным видом для соединения разнородных металлов. Основными преимуществами лазерной сварки в этой области являются прецизионность воз действия, возможность точного контроля процесса плавления соединяемых материалов и малое время пребывания свариваемых материалов в расплавленном состоянии, что способствует минимизации образования интер металлидного слоя, являющегося основной проблемой при сварке плохо свариваемых металлов. Также меньшее удельное тепловложение способствует минимизации термических деформаций.

2. При сварке внахлест или аналогичных соединениях стали и алюминия лазерный луч рационально направлять на сталь, посредством тепловой кондукции сталь нагревает алюминий, что приводит к контролируемому плав лению его поверхности и образованию минимального ИМС в сварно-паяном соединении.

3. Соединение встык данных пар металлов, как правило, характеризуется как сварно-паянное соединения, то есть для алюминия это сварка, а для стали пайка. В данном случае наиболее предпочтительной является техника смеще ния лазерного луча на алюминий, который имеет более низкую температуру плавления и хорошую смачиваемость стали в жидком состоянии. Предел прочности таких соединений достигает 150-160 МПа, что составляет 70-80\% от прочности свариваемых алюминиевых сплавов и является приемлемым для некоторых конструкций.

В следующей статье будут представлены материалы и результаты исследований по сварке таких пар металлов как титан + сталь, сталь + никель, титан + алюминий, никель + титан и т.д. with steel in the lower and upper parts of the joint and, as a result, to the formation of an IML that is more uniform in thickness $(-1.3 \mu \mathrm{m})$. By shifting the laser beam by $0.8 \mathrm{~mm}$, joints were obtained having a tensile strength of about $160 \mathrm{MPa}$. The authors also presented a model of the interaction of aluminum and iron atoms and a model of the formation of IML depending on the displacement distance.

The rest of the works describe the influence of methods, basic technological parameters, techniques and approaches, such as the choice of filler material, shielding gas, the use of various coatings of the metals to be joined, the use of two-beam laser welding, several works on remote high-speed welding have been published.

\section{CONCLUSION}

The research results lead to the following conclusions:

1. Laser welding is a promising type for joining dissimilar metals. The main advantages of laser welding in this area are the precision of the action, the ability to accurately control the melting process of the materials to be joined, and the short residence time of the materials being welded in the molten state, which helps to minimize the formation of an intermetallic layer, which is the main problem in welding poorly welded metals. In addition, lower specific heat input helps to minimize thermal deformations.

2. With overlap welding or welding of similar joints of steel and aluminum, it is rational to direct the laser beam to the steel, through thermal conduction, the steel heats the aluminum, which leads to controlled melting of its surface and the formation of a minimal IML in the welded-soldered joint.

3. The butt joint of these pairs of metals, as a rule, is characterized as a welded-brazed joint, that is, for aluminum it is welding, and for steel it is brazing. In this case, the most preferable is the technique of shifting the laser beam to aluminum, which has a lower melting point and good wettability of steel in a liquid state. The ultimate strength of such joints reaches $150-160 \mathrm{MPa}$, which is $70-80 \%$ of the strength of the welded aluminum alloys and is acceptable for some structures.

The next part of the paper will present materials and research results on welding of such metal pairs as titanium + steel, steel + nickel, titanium + aluminum, nickel + titanium, etc. 


\section{СПИСОК ЛИТЕРАТУРЫ}

1. Антипов В. В., Серебренникова Н. Ю. Коновалов А. Н., Нефедова Ю. Н. Перспективы применения в авиационных конструкциях слоистых металлополимерных материалов на основе алюминиевых сплавов. Авиационные материалы и технологии. 2020; 58: 45-53.

2. Башин К.А., Торсунов Р.А. Семенов С. В. Методы топологической оптимизации конструкций, применяющихся в аэрокосмической отрасли. Вестник Пермского национального исследовательского политехнического университета. Аэрокосмическая техника. 2017; 51: 51-61.

3. Скляр, М. О., Туричин, Г.А., Климова, О. Г., Зотов, О.Г., Топалов, И. К. Исследование влияния параметров прямого лазерного выращивания на микроструктуру изделий из стали 316L. Cтапь. 2016; 12: 71-75.

4. Martinsen K., Hu S. J., Carlson B. E. Joining of dissimilar materials. CIRP Annals - Manufacturing Technology. 2015; 64: 679-699. DOI: 10.1016/j.cirp.2015.05.006.

5. Ряблов В. Р., Рабкин Д. М., Курочко Р. С., Стрижевская Л. Г. Сварка разнородных метаппов и сппавов. - М.: Машиностроение. 1984. 239 с.

6. Лашко С. В., Лашко Н. Ф. Пайка метаппов. 4-е изд., перераб. и доп. - М. Изд. Машиностроение, 1988. 376 С.

7. Закиров И. М., Сосов А. В., Никитин А. В., Луканкин С. А. Испытание клинч-соединения на прочность. Вестник Казанского государственного технического университета им. А. Н. Тупопева. 2012; 4(2): 58-60.

8. Арзамасов Б. Н., Макарова В. И., Мухин Г. Г. Материаповедение: учебник дия вузов / З-е изд., стереотип. - М: Изд-во МГТУ им. Н. Э. Баумана. 2002. 648 C.

9. Люшинский А. В. Диффузионная сварка разнородных материапов. Учебное пособие для студентов вузов / А. В. Люшинский. - М: Машиностроение. 2006. 208 с. Сер. Высшее профессиональное образование.

10. Григорянц А. Г., Шиганов И. Н., Мисюров А. И. Технологические процессы пазерной обработки / Учебн. пособие для ВУзов. - М.: Изд-во МГТУ им. Н. Э. Баумана. 2006. 664 С.

11. Шиганов И. Н., Курынцев С. В. Современные тенденции лазерной сварки. Часть І. Наукоемкие технологии в машиностроении. 2015; 6: 35-42.

\section{REFERENCES}

1. Antipov V. V., Serebrennikova N. YU. Konovalov A. N., Nefedova YU. N. Perspektivy primeneniya v aviacionnyh konstrukciyah sloistyh metallopolimernyh materialov na osnove alyuminievyh splavov. Aviacionnye materialy i tekhnologii. 2020; 58: 45-53.

2. Bashin K. A., Torsunov R. A. Semenov S. V. Metody topologicheskoj optimizacii konstrukcij, primenyayushchihsya v aerokosmicheskoj otrasli. Vestnik Permskogo nacional'nogo issledovatel'skogo politekhnicheskogo universiteta. Aerokosmicheskaya tekhnika. 2017; 51: 51-61.

3. Sklyar, M. O., Turichin, G.A., Klimova, O.G., Zotov, O.G., Topalov, I. K. Issledovanie vliyaniya parametrov pryamogo lazernogo vyrashchivaniya na mikrostrukturu izdelij iz stali 316L. Stal'. 2016; 12: 71-75

4. Martinsen K., Hu S. J., Carlson B. E. Joining of dissimilar materials CIRP Annals - Manufacturing Technology. 2015; 64: 679-699. DOI: 10.1016 / j. cirp.2015.05.006

5. Ryablov V. R., Rabkin D. M., Kurochko R. S., Strizhevskaya L. G. Svarka raznorodnyh metallov i splavov. - M.: Mashinostroenie. 1984. 239 pp.

6. Lashko S. V., Lashko N. F. Pajka metallov. 4-e izd., pererab. i dop. - M.: Izd Mashinostroenie, 1988. 376 pp.

7. Zakirov I. M., Sosov A. V., Nikitin A. V., Lukankin S. A. Ispytanie klinch-soedineniya na prochnost'. Vestnik Kazanskogo gosudarstvennogo tekhnicheskogo universiteta im. A. N. Tupoleva. 2012; 4(2): 58-60.

8. Arzamasov B. N., Makarova V. I., Muhin G. G. Materialovedenie: uchebnik dlya vuzov / 3-e izd., stereotip. - M: Izd-vo MGTU im. N. E. Baumana. 2002. 648 pp.

9. Lyushinskij A.V. Diffuzionnaya svarka raznorodnyh materialov. M: Mashinostroenie. 2006. 208 pp. Ser. Vysshee professional'noe obrazovanie.

10. Grigoryanc A. G., SHiganov I.N., Misyurov A. I. Tekhnologicheskie processy lazernoj obrabotki. - M.: Izd-vo MGTU im. N.E Baumana. 2006. $664 \mathrm{pp}$

11. SHiganov I. N., Kuryncev S. V. Sovremennye tendencii lazernoj svarki. Part I. Naukoemkie tekhnologii v mashinostroenii. 2015; 6: 35-42.
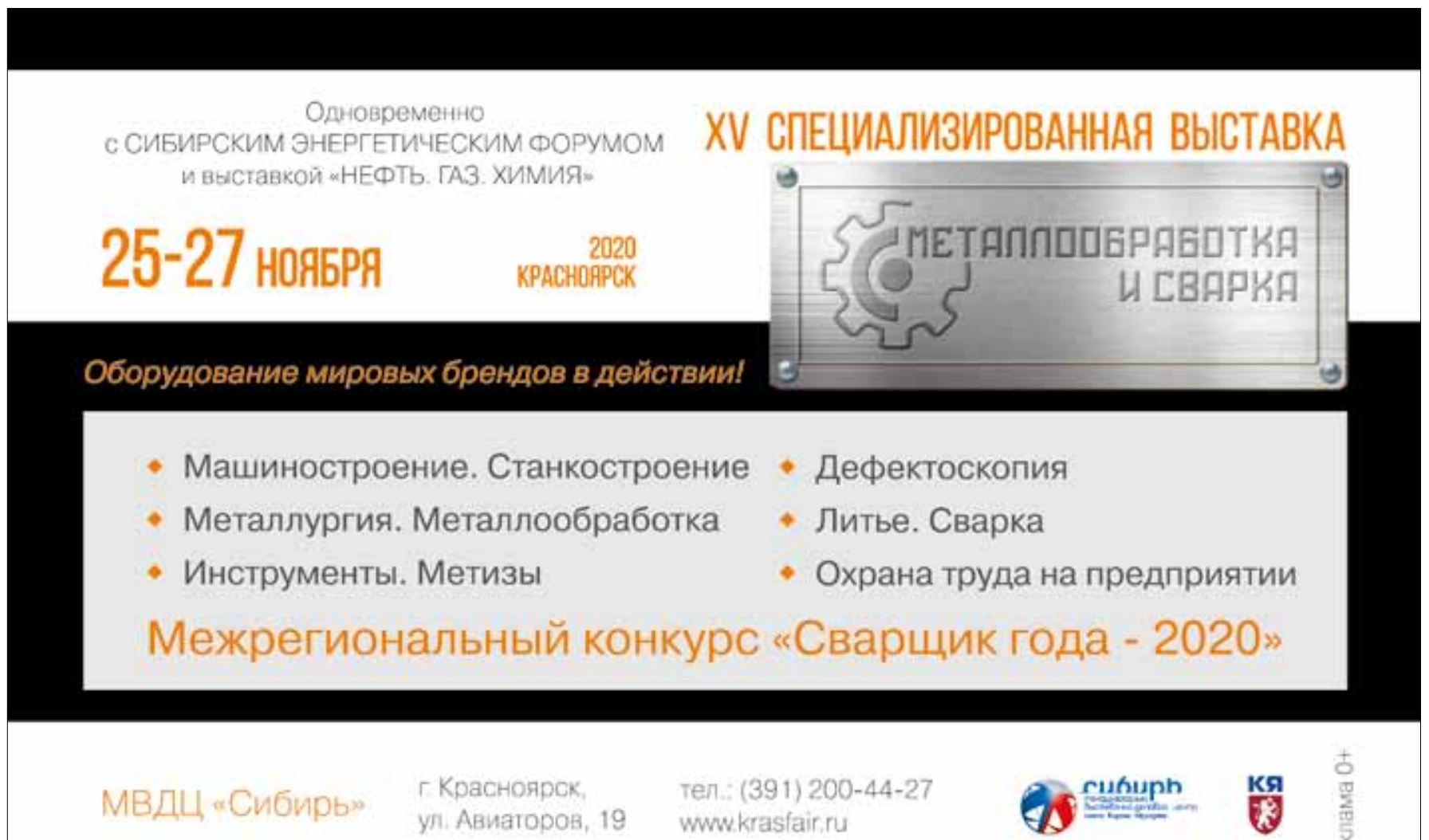
12. Шиганов И. Н., Курынцев С. В. Современные тенденции лазерной сварки. Часть II. Наукоемкие технологии в машиностроении. 2015; 9: 15-20.

13. Патент RU2678002 C1. Способ соединения металлического материала с композиционным материалом лазерным лучом / Курынцев С. В.

14. Курынцев С. В., Шиганов И. Н. Сварка аустенитной стали с медью расфокусированным излучением волоконного лазера. Сварочное производство. 2017; 4: 7-11.

15. Лукин М. А. Контактная стыковая сварка оплавлением пакета алюминиевых листов со стальным стержнем. Сварочное производство. 2020; 3: 38-43.

16. Frank S. Flux-free laser joining of aluminum and galvanized steel. Journal of Materials Processing Technology. 2015, 222: 365-372. DOI: 10.1016/j.jmatprotec.2015.03.032.

17. Li LQ, Xia HB, Tan CW, Ma NS. Effect of groove shape on laser weldingbrazing Al to steel. Journal of Materials Processing Technology. 2018; 252:573-81. DOI: 10.1016/j.jmatprotec.2017.10.025

18. Seffer O, Pfeifer R, Springer A, Kaierle S. Investigations on laser beam welding of different dissimilar joints of steel and aluminum alloys for automotive lightweight construction. Laser Assisted Net Shape Engineering 9 International Conference on Photonic Technologies Proceedings of the Lane 2016. 2016; 83:383-95. DOI: 10.1016/j.phpro.2016.08.040.

19. Meco S, Cozzolino L, Ganguly S, Williams S, McPherson N. Laser welding of steel to aluminium: Thermal modelling and joint strength analysis. Journal of Materials Processing Technology. 2017;247:121-33. DOI: 10.1016/j. jmatprotec.2017.04.002.

20. Cui L, Chen HX, Chen BX, He DY. Welding of Dissimilar Steel / Al Joints Using Dual-Beam Lasers with Side-by-Side Configuration. Metals. 2018; 8(12):21. DOI: 10.3390 / met8121017.

21. Люхтер А. Б., Шлегель А. Н., Леонтьев А. А., Гусев Д. С. Результаты механических испытаний корпусных элементов автобусов, полученных лазерной сваркой стального профиля СтЗ С алюминиевой облицовкой АМг2М. Цветные метапиы. 2017; 10: 85-89.

22. Casalino G, Leo P, Mortello M, Perulli P, Varone A. Effects of Laser Offset and Hybrid Welding on Microstructure and IMC in Fe-Al Dissimilar Welding. Metals. 2017;7(8). DOI: 10.3390 / met7080282.

23. Huang JK, He J, Yu XQ, Li CL, Fan D. The study of mechanical strength for fusion-brazed butt joint between aluminum alloy and galvanized steel by arc-assisted laser welding. Journal of Manufacturing Processes. 2017; 25:126-33. DOI: 10.1016 / j.jmapro.2016.11.014.

24. Nothdurft S, Prasanthan V, Denkena B, Breidenstein B, Grove $\mathrm{T}$, Ohrdes $\mathbf{H}$, et al. Surface Integrity of Laser Beam Welded SteelAluminium Alloy Hybrid Shafts after Turning. Metals. 2019; 9(2). DOI: 10.3390 / met9020134

25. Meco S, Ganguly S, Williams S, McPherson N. Design of laser welding applied to $\mathrm{T}$ joints between steel and aluminium. Journal of Materials Processing Technology. 2019; 268:132-9. DOI: 10.1016 / j.jmatprotec.2019.01.003.

26. Meng YF, Gong MC, Zhang S, Zhang YZ, Gao M. Effects of oscillating laser offset on microstructure and properties of dissimilar Al / steel butt-joint. Optics and Lasers in Engineering. 2020;128. DOI: 10.1016/j. optlaseng.2020.106037.

\section{АВТОРЫ}

Курынцев Сергей Вячеславович, канд. эконом. наук,

E-mail: kuryntsev16@mail.ru, Казанский национальный исследовательский технический университет им. А. Н. Түполева - КАИ, Казань, Россия.

Шиганов Игорь Николаевич, доктор техн. наук, профессор, Московский государственный технический университет им. Н. Э. Баумана, Москва, Россия.

\section{ВКЛАД АВТОРОВ}

Курынцев С. В. - идея, перевод и анализ материала, работа с графической частью, обработка результатов. Шиганов И. Н. - обсуждение, предложения и замечания, анализ материалов.

\section{ИНФОРМАЦИЯ О КОНФЛИКТЕ ИНТЕРЕСОВ}

Авторы заверяют, что не имеют реального или потенциального конфликта интересов.
12. SHiganov I. N., Kuryncev S. V. Sovremennye tendencii lazernoj svarki. Part II. Naukoemkie tekhnologii v mashinostroenii. 2015; 9: 15-20.

13. Patent RU2678002 Cl. Sposob soedineniya metallicheskogo materiala s kompozicionnym materialom lazernym luchom / Kuryncev S. V.

14. Kuryncev S. V., SHiganov I. N. Svarka austenitnoj stali s med'yu rasfokusirovannym izlucheniem volokonnogo lazera. Svarochnoe proizvodstvo. 2017; 4: 7-11

15. Lukin M. A. Kontaktnaya stykovaya svarka oplavleniem paketa alyuminievyh listov so stal'nym sterzhnem. Svarochnoe proizvodstvo. 2020; 3: 38-43.

16. Frank S. Flux-free laser joining of aluminum and galvanized steel. Journal of Materials Processing Technology. 2015, 222: 365-372. DOI: 10.1016/j. jmatprotec.2015.03.032

17. Li LO, Xia HB, Tan CW, Ma NS. Effect of groove shape on laser weldingbrazing Al to steel. Journal of Materials Processing Technology. 2018; 252:57381. DOI: 10.1016 / j.jmatprotec.2017.10.025

18. Seffer O, Pfeifer R, Springer A, Kaierle S. Investigations on laser beam welding of different dissimilar joints of steel and aluminum alloys for automotive lightweight construction. Laser Assisted Net Shape Engineering 9 International Conference on Photonic Technologies Proceedings of the Lane 2016. 2016; 83:383-95. DOI: 10.1016/j.phpro.2016.08.040.

19. Meco S, Cozzolino L, Ganguly S, Williams S, McPherson N. Laser welding of steel to aluminium: Thermal modelling and joint strength analysis. Journal of Materials Processing Technology. 2017;247:121-33. DOI: 10.1016 / j.jmatprotec.2017.04.002.

20. Cui L, Chen HX, Chen BX, He DY. Welding of Dissimilar Steel / Al Joint Using Dual-Beam Lasers with Side-by-Side Configuration. Metals. 2018; 8(12):21. DOI: 10.3390 / met8121017.

21. Lyuhter A. B., SHlegel' A. N., Leont'ev A. A., Gusev D. S. Rezul'taty mekhanicheskih ispytanij korpusnyh elementov avtobusov, poluchennyh lazernoj svarkoj stal'nogo profilya St3 s alyuminievoj oblicovkoj AMg2M. Cvetnye metally. 2017; 10: 85-89.

22. Casalino G, Leo P, Mortello M, Perulli P, Varone A. Effects of Laser Offset and Hybrid Welding on Microstructure and IMC in Fe-Al Dissimilar Welding. Metals. 2017; 7(8). DOI: 10.3390 / met7080282.

23. Huang JK, He J, Yu XQ, Li CL, Fan D. The study of mechanical strength for fusion-brazed butt joint between aluminum alloy and galvanized steel by arc-assisted laser welding. Journal of Manufacturing Processes. 2017; 25:12633. DOI: 10.1016 / j.jmapro.2016.11.014

24. Nothdurft S, Prasanthan V, Denkena B, Breidenstein B, Grove T, Ohrdes $\mathrm{H}$, et al. Surface Integrity of Laser Beam Welded SteelAluminium Alloy Hybrid Shafts after Turning. Metals. 2019; 9(2). DOI: 10.3390 / met9020134

25. Meco S, Ganguly S, Williams S, McPherson N. Design of laser welding applied to $T$ joints between steel and aluminium. Journal of Materials Processing Technology. 2019; 268:132-9. DOI: 10.1016 / j. jmatprotec.2019.01.003.

26. Meng YF, Gong MC, Zhang S, Zhang YZ, Gao M. Effects of oscillating laser offset on microstructure and properties of dissimilar Al / steel butt-joint. Optics and Lasers in Engineering. 2020;128. DOI: 10.1016 / j optlaseng.2020.106037.

\section{ABOUT AUTHORS}

Kuryntsev Sergey V., Candidate of Sciences (Economics), e-mail kuryntsev16@mail. ru, Kazan National Research Technical University named after A. N. Tupolev KAl, Kazan, Russia.

Igor Nikolaevich Shiganov, Doctor of Technical Sciences, Professor, Moscow State Technical University named after N. E. Moscow, Russia.

\section{CONTRIBUTIONS OF AUTHORS}

Kuryntsev S. V. - idea, translation and analysis of material, work with graphic part, results processing. Shiganov I. N. - discussion, suggestions and comments, material analysis

\section{CONFLICT OF INTEREST}

The authors declare no real or potential conflicts of interest. 